\title{
Acid stress response and protein induction in Campylobacter jejuni isolates with different acid tolerance
}

Tina Birk ${ }^{1,2}$, Monica Takamiya Wik', René Lametsch ${ }^{1}$ and Susanne Knøchel ${ }^{{ }^{*}}$

\begin{abstract}
Background: During the transmission route from poultry to the human host, the major foodborne pathogen $C$. jejuni may experience many types of stresses, including low pH caused by different acids. However, not all strains are equally sensitive to the stresses. The aim of this study was to investigate the response to acid stress of three sequenced $\mathrm{C}$. jejuni strains with different acid tolerances using $\mathrm{HCl}$ and acetic acid.

Results: Two-dimensional gel electrophoresis was used for proteomic analysis and proteins were radioactively labelled with methionine to identify proteins only related to acid exposure. To allow added radioactive methionine to be incorporated into induced proteins, a modified chemically defined broth was developed with the minimal amount of methionine necessary for satisfactory growth of all strains. Protein spots were analyzed using image software and identification was done with MALDI-TOF-TOF. The most acid-sensitive isolate was C. jejuni 327, followed by NCTC 11168 and isolate 305 as the most tolerant. Overall, induction of five proteins was observed within the pl range investigated: $19 \mathrm{kDa}$ periplasmic protein (p19), thioredoxin-disulfide (TrxB), a hypothetical protein Cj0706 (Cj0706), molybdenum cofactor biosynthesis protein (MogA), and bacterioferritin (Dps). Strain and acid type dependent differences in the level of response were observed. For strain NCTC 11168, the induced proteins and the regulator fur were analysed at the transcriptomic level using qRT-PCR. In this transcriptomic analysis, only up-regulation of trxB and 19 was observed.

Conclusions: A defined medium that supports the growth of a range of Campylobacter strains and suitable for proteomic analysis was developed. Mainly proteins normally involved in iron control and oxidative stress defence were induced during acid stress of $C$. jejuni. Both strain and acid type affected sensitivity and response.
\end{abstract}

\section{Background}

Campylobacter jejuni is a leading cause of foodborne disease with poultry as a common vector. During the transmission route to the human host, $C$. jejuni may experience many types of stresses such as exposure to oxygen in the environment, large temperature shifts, and changes in $\mathrm{pH}$. Compared with many other foodborne pathogens, $C$. jejuni is more sensitive towards stress such as acid [1-3] and has stringent requirements for optimal growth conditions [4].

During colonization of the human host, C. jejuni is exposed to low $\mathrm{pH}$ environments. At first, the bacteria

\footnotetext{
* Correspondence: skn@life.ku.dk

${ }^{1}$ Department of Food Science, Faculty of Sciences Copenhagen University, Rolighedsvej 30, 1958, Frederiksberg C, Denmark

Full list of author information is available at the end of the article
}

are exposed to inorganic acid $\left(\mathrm{H}^{+}\right)$in the gastric fluid of the stomach and later to organic acids in the small intestine $[5,6]$. The capacity to counteract environmental stresses is fundamental for survival. Bacteria respond to decreases in $\mathrm{pH}$ by inducing different systems to maintain $\mathrm{pH}$ homeostasis. These systems may prevent entry of $\mathrm{H}^{+}$, extrusion of $\mathrm{H}^{+}$from the cell, consumption of $\mathrm{H}^{+}$ in chemical reactions or the repair of damaged cellular material. In some bacteria, such as Salmonella and Listeria, exposure to acid can up-regulate the $\mathrm{F}_{0} \mathrm{~F}_{1}$-ATPase $[7,8]$ by hydrolysis of ATP pump $\mathrm{H}^{+}$out of the cell [9]. Amino acid decarboxylation acid resistance systems are found in many bacteria [10-12], however, these systems have not been identified in C. jejuni [13].

Compared to other bacteria, C. jejuni is more sensitive to stress and has a limited number of stress regulators.

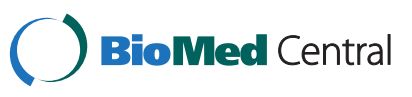


C. jejuni lacks the global stationary-phase regulator, sigma factor RpoS, which induces expression of numerous proteins involved in different forms of stress responses [14] and it is also involved in acid stress in $E$. coli and Salmonella $[15,16]$. In addition, C. jejuni also lacks the oxidative stress response regulatory elements SoxRS and OxyR, and osmotic shock protectants such as BetAB [13,17]. However, C. jejuni does contain the global ferric uptake regulator (Fur) that regulates genes in response to iron transport, metabolism, and oxidative stress defence [18-20] and is involved in acid stress in Salmonella and Helicobacter pylori [21,22]. Compared with many other foodborne pathogens, $C$. jejuni is more sensitive to acid exposure [23]. This sensitivity is probably not only due to the lack of an acid resistance system but also to the lack of the mentioned regulatory proteins. How then does $C$. jejuni respond on the proteomic level when exposed to low $\mathrm{pH}$ ?

Recently, a transcriptomic analysis of C. jejuni NCTC 11168 found changes in the expression of hundreds of genes upon acid shock or in a simulated gastric environment. Primarily, genes involved in encoding ribosomal proteins, transcription and translation, and amino acid biosynthesis were down-regulated [24]. Many of the genes up-regulated by acid stress in that study have previously been characterized as heat shock and oxidative stress genes [24]. However, microarray data are complex and all the up-regulated genes do not necessarily translate into changes in specific proteins vital for survival $[25,26]$.

Here, we want to analyze the acid stress response of $C$. jejuni strains with different acid sensitivity. Since weak and strong acids have different modes of action on the bacterial cell $[15,27]$, the acid induced response to both a weak acid, acetic acid, which can be encountered in foods) and a strong acid ( $\mathrm{HCl}$, which is found in the gastric fluid) was analyzed and compared.

Proteins synthesized during stress were labelled by incorporation of radioactive methionine and separated by two-dimensional (2D) electrophoresis. At first, a chemically defined broth (CDB) suitable for growth of different $C$. jejuni strains therefore had to be developed with minimal concentrations of methionine in order to minimize competition with radioactive methionine added upon stress exposure.

\section{Methods}

\section{Bacterial strains and preparation of inocula}

Three sequenced $C$. jejuni strains were tested for acid stress response: the clinical human isolate $C$. jejuni NCTC 11168 from the National Collection of Type Cultures, strain 305 (GeneBank accession number ADHL00000000 [28]) and strain 327 (GeneBank accession number ADHM00000000 [29]). Strains 305 and 327 were originally isolated from turkey production by Prof. Thomas Alter, Freie Universität, Berlin. Previous results (Birk et al. 2010, data not shown [23]) have found that strain 305 was less sensitive towards tartaric acid, and strain 327 was more sensitive to tartaric acid than the NCTC 11168, respectively. Strain 305 was denoted as acid-tolerant and strain 327 as acid-sensitive. During propagation and growth, all plates were incubated at $42^{\circ} \mathrm{C}$ in sealed gas jars under micro-aerobic conditions $\left(5 \% \mathrm{O}_{2}\right.$, $10 \% \mathrm{CO}_{2}, 85 \% \mathrm{~N}_{2}$ ). Stocks of all strains were stored at $-80^{\circ} \mathrm{C}$ in broth (BHI) (Oxoid CM225, England) containing $15 \%$ glycerol. From $-80^{\circ} \mathrm{C}$ stocks, cultures were transferred to Blood Agar Base No. 2 (Oxoid CM271, England) supplemented with 5\% horse blood and incubated for 3-4 days. One loop full of each culture was subsequently streaked onto new Blood Agar Base No. 2 plates. After 24 hours of growth, cells were harvested with $2 \mathrm{ml}$ phosphate-buffered saline (PBS) (Oxoid BR0014, England). The harvested cells were adjusted to $\mathrm{OD}_{600}=$ 0.1 which has previously shown to correspond to approx. $8 \log _{10} \mathrm{CFU} / \mathrm{ml}$ and subsequently used as inoculum.

\section{Preparation of chemically defined broth}

A chemically defined medium, originally developed for $N$. gonorrhoeae [30], was modified in order to have an optimal broth to support growth of Campylobacter on plates. From the original medium, glucose was removed because Campylobacter is unable to ferment or oxidize hexose carbohydrates [31], and different amino acids were added. The required amino acids were determined from the amino acid metabolic pathway maps listed for C. jejuni NCTC 11168 in the Kyoto Encyclopedia of Genes and Genomes (KEGG) [32] Pathway Database. If metabolic enzymes were lacking or if the amino acid biosynthetic pathway was complex, the specific amino acid was added to the modified chemically defined broth (CDB).

Modified CDB was prepared in double-strength stock batches (see Table 1) without methionine and cysteine, which were added later. The double-strength CDB was stored at $-20^{\circ} \mathrm{C}$. Prior to the experiments, doublestrength $\mathrm{CDB}$ was thawed at $4^{\circ} \mathrm{C}$ and diluted to single strength with MilliQ water (Table 1). Methionine and freshly prepared cysteine were added and the $\mathrm{pH}$ was adjusted to 7.0. Finally, the CDB was sterilized by filtration (pore size: $0.2 \mu \mathrm{m}$ ).

Individual stock solutions were prepared before the mixing of CDB. 10X buffer solution and 20X salt solution were made, autoclaved for $15 \mathrm{~min}$ at $121^{\circ} \mathrm{C}$, and stored at room temperature. The amino acid mix 1 (100X) was made in concentrations as listed in Table 1. However, methionine was prepared as an individual amino acid stock solution so the chemically defined broth could be prepared with different methionine 
Table 1 Components of modified chemically defined broth (CDB) for Campylobacter jejuni

\begin{tabular}{|c|c|c|c|}
\hline Components & $\begin{array}{l}\text { Stock } \\
\text { solution } \\
\text { (mg/ml) }\end{array}$ & $\begin{array}{l}\text { Vol stock } \\
\text { solution (ml) } \\
\text { for } 1 \text { liter }\end{array}$ & $\begin{array}{l}\text { Final conc } \\
\text { (mmol/l) of } \\
1 \times \mathrm{xCDB}\end{array}$ \\
\hline Buffer solution (10X) & & 100.0 & \\
\hline $\mathrm{K}_{2} \mathrm{HPO}_{4}$ & 34.8 & & 20.0 \\
\hline $\mathrm{KH}_{2} \mathrm{PO}_{4}$ & 27.2 & & 20.0 \\
\hline Salt solution (20X) & & 50.0 & \\
\hline $\mathrm{NaCl}$ & 116.0 & & 100.00 \\
\hline $\mathrm{K}_{2} \mathrm{SO}_{4}$ & 20.0 & & 5.74 \\
\hline $\mathrm{MgCl}_{2}, 6 \mathrm{H}_{2} \mathrm{O}$ & 8.2 & & 2.02 \\
\hline $\mathrm{NH}_{4} \mathrm{Cl}$ & 4.4 & & 4.11 \\
\hline EDTA & 0.074 & & 0.01 \\
\hline
\end{tabular}

Amino acid mix 1 (100X)

L-Arginine $\mathrm{HC}$

L-serine

L-leucine

L-isoleucine

L-valine

L-proline

L-phenylalanine

L-alanine

L-histidine

L-threonine

L-lysine

L-glycine

L-trypthophan

Amino acid mix 2 (10X)

L-aspartate

L-glutamate

Individual amino acids

L-cysteine/HCl +

L-cysteine $\dagger$

L-methionine

Vitamin mix (50X)

NAD

Thiamine $\mathrm{HCl}$ (Vitamine $\mathrm{B}_{1}$ )

Calcium pantothenate

(Vitamine $B_{5}$ )

Individual components

Oxaloacetate, $2 \mathrm{H}_{2} \mathrm{O}$ (10X)

$\mathrm{NaHCO}_{3}$ (2000X)

Biotin (Vitamine H) (500X)

$\mathrm{Fe}\left(\mathrm{NO}_{3}\right)_{3}, 9 \mathrm{H}_{2} \mathrm{O}(1000 \mathrm{X})$

$\mathrm{CaCl}_{2}, 2 \mathrm{H}_{2} \mathrm{O}(1000 X)$
Table 1 Components of modified chemically defined broth (CDB) for Campylobacter jejuni (Continued)

\begin{tabular}{l} 
Total $(\mathrm{ml})$ \\
MilliQ water $(\mathrm{ml}){ }^{*}$ \\
\hline The broth was prepared as described in the text. \\
*: To make portions of $500 \mathrm{ml} 2 \times \mathrm{CDB}$ without methionine and cysteine, only \\
$127.8 \mathrm{ml}$ of MilliQ water was added. The batches were sterilized by filtration, \\
aliquoted, and stored at $-20^{\circ} \mathrm{C}$. \\
†: Cysteine was prepared freshly and dissolved in $1 \mathrm{M} \mathrm{HCl}$ prior to each \\
experiment.
\end{tabular}

concentrations. The amino acid mix, vitamin mix and the individual components were sterilized by filtration and stored at $-20^{\circ} \mathrm{C}$ until use. Stock solutions of cysteine were prepared just prior to use.

\section{Growth in chemically defined broth}

In the growth experiment, $C$. jejuni strains NCTC 11168,305 , and 327 were tested for growth in CDB containing various concentrations of methionine $(0.1 \mathrm{mM}$, $0.01 \mathrm{mM}, 0.001 \mathrm{mM}$, and $0 \mathrm{mM}$ ) and compared with growth in BHI (Scharlau 02-1599, Spain) (Figure 1). From each inoculum, $12.5 \mu \mathrm{l}$ was transferred to $25 \mathrm{ml}$ pre-heated $\mathrm{CDB}\left(37^{\circ} \mathrm{C}\right)$ resulting in $4.95( \pm$ S.D. $=0.21)$ $\log _{10} \mathrm{CFU} / \mathrm{ml}$. Growth of another 10 strains was compared in BHI and CDB with $0.01 \mathrm{mM}$ (data not shown).

\section{Microbiological analyses and sampling}

C. jejuni cultures were serially 10-fold diluted in maximum recovery diluent (MRD) (Oxoid CM733, England) and $3 \times 10 \mu \mathrm{l}$ of appropriate dilutions were spotted onto Blood Agar Base No. 2 (Oxoid CM271, England) supplemented with $5 \%$ horse blood. After $24-48$ h of incubation under microaerobic conditions, colonies were counted and the numbers of colony-forming units (CFU) per ml were determined.

\section{In vitro acid stress and [ $\left.{ }^{35} \mathrm{~S}\right]$-methionine labelling and protein extraction}

The response of $C$. jejuni to a strong acid $(\mathrm{HCl})$ and a weak acid (acetic acid) was tested. These two different acids were selected because Campylobacter encounters $\mathrm{HCl}$ in the stomach and may be exposed to acetic acid during food processing. The cell cultures were adjusted to $\mathrm{pH}=5.2$ for $\mathrm{HCl}$ and $\mathrm{pH}=5.7$ for acetic acid since these values reduced growth rate to the same level for the most acid-tolerant strain 305 (Figure 2C). Three independent biological replicates were performed for each strain under two different acid stress conditions.

From the inoculum, $100 \mu \mathrm{l}$ were transferred to $200 \mathrm{ml}$ pre-heated $\mathrm{CDB}\left(37^{\circ} \mathrm{C}\right)$ containing $0.01 \mathrm{mM}$ methionine resulting in approximately $5 \log _{10} \mathrm{CFU} / \mathrm{ml}$. C. jejuni strains NCTC 11168, 305, and 327 were grown to late exponential phase at $37^{\circ} \mathrm{C}$ to ensure high metabolic activity and overcome problems due to very low protein 


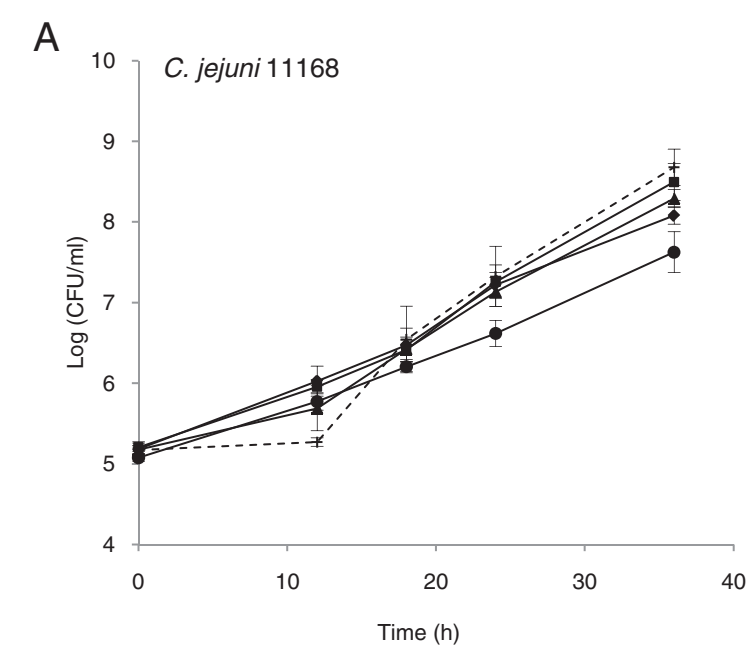

B

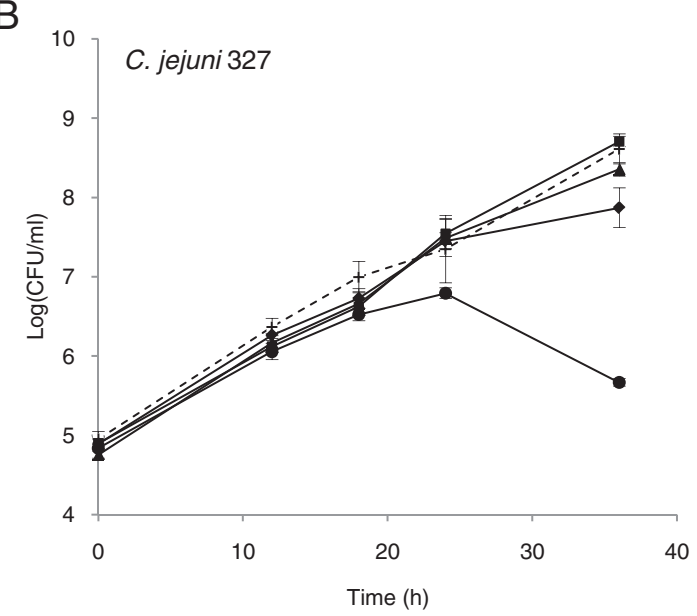

C

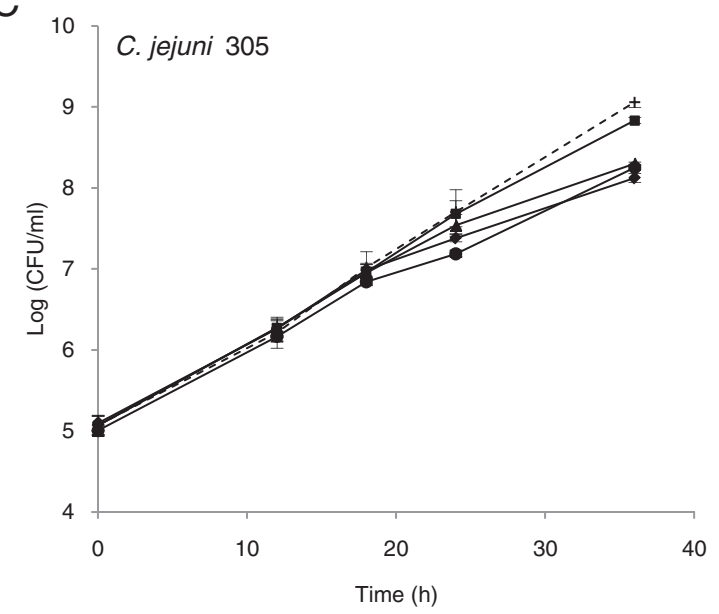

Figure 1 Growth of the different Campylobacter jejuni strains in chemically defined broth (CDB) containing different concentrations of methionine. Strains 11168 (A), 327 (B), and 305 (C) grown at $37^{\circ} \mathrm{C}$ in a microaerobic atmosphere in brain heart infusion (BHI) broth (dashed curve) and modified CDB containing 0.1 $\mathrm{mM}(\boldsymbol{\bullet}), 0.01 \mathrm{mM}(\boldsymbol{\Delta}), 0.001 \mathrm{mM}(\bullet)$, and no $(\bullet)$ methionine, respectively. Error bars represent the standard deviation for three replicates. outcome in earlier phases (data not shown). After 26 hours of growth for strains 327 and NCTC 11168 and 22 hours for strain 305, the number of cells corresponded to approximately $8 \log _{10} \mathrm{CFU} / \mathrm{ml}$. Then $50 \mathrm{ml}$ of the cell cultures (start $\mathrm{pH}$ about 7.0) were adjusted to $\mathrm{pH} 5.2$ with $\mathrm{HCl}$ and $\mathrm{pH} 5.7$ with acetic acid. Immediately after $2 \times 1 \mathrm{ml}$ cells were transferred to two tubes with screw cap, incubated for $20 \mathrm{~min}$ and labelled with $77 \mu \mathrm{Ci} / \mathrm{ml} \mathrm{L}-\left[\begin{array}{ll}35 & \mathrm{~S}\end{array}\right]$-methionine (Perkin Elmer, NEG709A Easy $\mathrm{Tag}^{\mathrm{ma}}$ ) for an additional $20 \mathrm{~min}$ at $37^{\circ} \mathrm{C}$. The 40 minutes exposure was chosen to reduce the effect of acid shock [33].

After acid exposure, the cells were decanted by centrifugation at $18,620 \times g$ (Hermle Z233) for $3 \mathrm{~min}$. For extraction of proteins, extraction buffer $[7 \mathrm{M}$ urea (GEHealthcare 17-131901), 2 M thiourea (Sigma-Aldrich, T7875), 4\% CHAPS (GE-Healthcare, 17-1314-01), IPG buffer 4-7 (GE-Healthcare, 17-6000-86), $20 \mathrm{mM}$ dithiothreitol (Sigma-Aldrich D-9779), $30 \mu \mathrm{g} / \mathrm{ml}$ chymostatin (Sigma-Aldrich, C7268), $15 \mu \mathrm{g} / \mathrm{ml}$ pepstatin (SigmaAldrich, P4265), $174 \mu \mathrm{g} / \mathrm{ml}$ phenylmethylsulfonyl fluoride (Sigma-Aldrich, P7626)], and $50 \mathrm{mg}$ glass beads $(\mathrm{D}=1$ $\mathrm{mm}$, Struers Kebolab, 115-790-1) were added for cell lysis in a FastPrep at speed 6 for 45 seconds. The suspension was centrifuged at $4^{\circ} \mathrm{C}$ at $18,620 \times g$ (Hermle Z233) for 10 min and exactly $2 \times 30 \mu \mathrm{l}$ of protein sample was transferred to a clean Eppendorf tube and prepared for 2D gel electrophoresis.

\section{Two-dimensional gel electrophoresis}

The protein sample was analyzed by using the GEHealthcare Multiphor II Electrophoresis Systems using Immobiline DryStrips for the first dimension and the BioRad Criterion Cell system for the second dimension. For rehydration, $60 \mu$ protein sample was mixed with $140 \mu \mathrm{l}$ rehydration solution [7 $\mathrm{M}$ urea (GE-Healthcare 17131901), $2 \mathrm{M}$ thiourea (Sigma-Aldrich, T7875), 4\% CHAPS (GE-Healthcare, 17-1314-01), IPG buffer 4-7 (GE-Healthcare, 17-6000-86), $20 \mathrm{mM}$ dithiothreitol (Sigma-Aldrich D-9779), and a few grains of bromphenol blue (Merck, 1.59102)] and applied to an 11-cm Immobiline DryStrip pH 4-7 (GE Healthcare, 18-1016-60) and the electrofocusing was run for a total of 18.2 hours (step 1: $300 \mathrm{~V}, 1 \mathrm{MA}$, $5 \mathrm{~W}, 0.01$ h; step 2: $300 \mathrm{~V}, 1 \mathrm{MA}, 5 \mathrm{~W}, 8 \mathrm{~h}$; step 3: $3500 \mathrm{~V}$, $1 \mathrm{MA}, 5 \mathrm{~W}, 5 \mathrm{~h}$; and step 4: $3500 \mathrm{~V}, 1 \mathrm{MA}, 5 \mathrm{~W}, 5.20 \mathrm{~h}$ ). Before protein separation by their molecular weight, the Immobiline DryStrips were equilibrated, first in $20 \mathrm{ml}$ equilibration buffer [6 $\mathrm{M}$ urea (GE-Healthcare 17131901), 50 mM Tris-HCl (Trizma Base, Sigma T-1503, $\mathrm{pH}$ 6.8), $30 \mathrm{v} / \mathrm{v} \%$ glycerol (Merck, 1.04094), 2 w/v\% SDS (GE-Healthcare, 17-1313-01)] containing $0.625 \mathrm{w} / \mathrm{v} \%$ dithiothreitol (DTT) (Sigma-Aldrich D-9779) for $15 \mathrm{~min}$ and then in $20 \mathrm{ml}$ equilibration buffer also containing 2.5 $\mathrm{w} / \mathrm{v} \%$ iodoacetamide (Sigma-Aldrich, I6525) and a few 


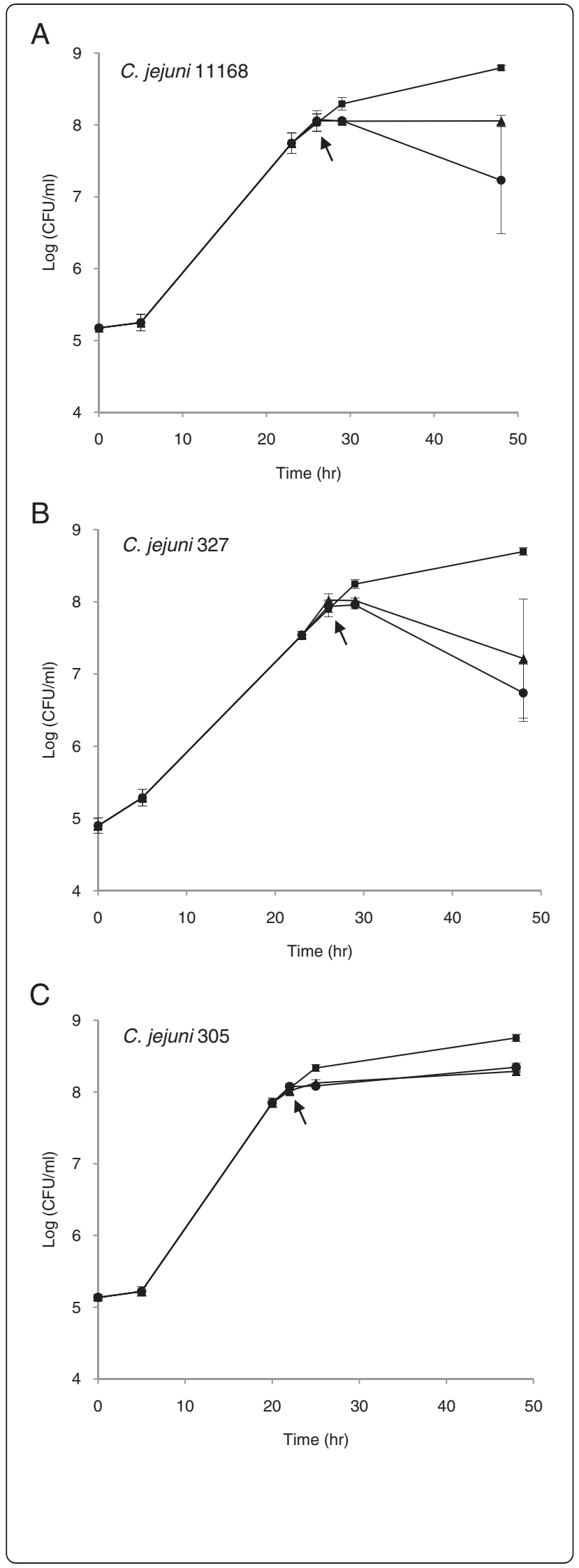

Figure 2 Growth, acid stress and $\left.{ }^{35} \mathrm{~S}\right]$-L-methionine labelling. C. jejuni strains were grown to late exponential phase in modified chemically defined broth (CDB) containing $0.01 \mathrm{mM}$ methionine at $37^{\circ} \mathrm{C}$ in a microaerophilic atmosphere. When cells had reached approximately $1 \times 10^{8} \mathrm{CFU} / \mathrm{ml}$, after 26 hours of growth for strains 11168 (A) and 327 (B) and after 22 hours for strain 305 (C), they were subjected to a shift in $\mathrm{pH}$. The cells were first exposed to $\mathrm{HCl}$ $(\mathrm{pH} 5.2, \bullet)$ and acetic acid (pH 5.7, $\mathbf{\Delta})$ for 20 min before radioactive labelling with $\left.{ }^{35} \mathrm{~S}\right]-\mathrm{L}$-methionine for an additional $20 \mathrm{~min}$. The control (घ) was labelled for $20 \mathrm{~min}$. The arrows indicate the point of labelling. After labelling, cells were harvested for proteome analysis. Data points are the mean of three replicates and standard variations are indicated by $\pm \operatorname{SEM}(n=3)$.

grains of bromphenol blue (Merck, 1.59102) for $15 \mathrm{~min}$. In the $2^{\text {nd }}$ dimension, the Criterion ${ }^{\mathrm{TM}}$ precast $10 \%-20 \%$ Tris-HCl Gel (Bio-Rad, 345-0107) gel was used for separation of proteins by size. After draining, the strips were sealed and connected to the gel by using $0.5 \%$ agarose and run in Laemmli running buffer [(30.3 g/l Trizma base (Sigma-Aldrich, T6066), 144 g/l glycine (Merck, 1.04201) and $10.0 \mathrm{~g} / \mathrm{l} \mathrm{SDS}$ (GE- Healthcare, 17-1313-01)]. The gels were stained using a silver staining kit (GE-Healthcare, 171150-01), coated with cellophane, dried overnight at room temperature, and exposed to phosphorus screens for $72 \mathrm{~h}$.

\section{Image and data analysis}

Radioactive proteins were visualized using a PhosphorImager (STORM 840, GE-Healthcare), and the protein spots were analyzed using the Image Master $^{\text {Tix }} 2 \mathrm{D}$ Platinum (version 5.0, GE-Healthcare). Initially, protein spots of one set of gels were matched and specific proteins that had higher intensity values than proteins from the control gel were annotated. One set of gels included $\mathrm{HCl}$ and acetic acids stressed cells plus a control as a reference. For comparative protein analysis, corresponding protein spots for each specific protein on the control, $\mathrm{HCl}$, and acetic acid gels were manually defined as one group and the match was automatically verified before estimating the volume intensity. The three replicates were compared by normalizing the estimated volume intensity for the individual proteins to percent volume intensity for each replicate. The percent volume intensity was calculated for the specific conditions (control, $\mathrm{HCl}$ and acetic acid) as follows:\% volume intensity control condition (protein $\mathrm{x}$ ) $=$ volume intensity condition/ (volume intensity control + volume intensity $\mathrm{HCl}+$ volume intensity acetic acid).

\section{In-gel digestion of protein spots}

To examine relevant protein spots, $C$. jejuni cells were exposed to acid stress without labelling them with methionine but the proteins were separated using the same procedure as for labelling. After the $2^{\text {nd }}$ dimension, and fixation in equilibration buffer [concentrated $\mathrm{H}_{3} \mathrm{PO}_{4}$ 
(VWR, 20621.295), $150 \mathrm{~g} / \mathrm{l}$ ammoniumsulfate (Merck, 1.01217), $18 \%$ ethanol] for $30 \mathrm{~min}$, the gel was stained with $1 \mathrm{ml} 20.0 \mathrm{~g} / \mathrm{l}$ Coomassie Brillant Blue $250 \mathrm{G}$ (Merck, 1.15444). Relevant protein spots were excised from the gel. The gel pieces were then washed and digested with trypsin as described by Sørensen et al. (2009) [34].

\section{Desalting, concentration, and loading on MALDI target} Gel-loader tips (Eppendorf) packed with Poros reverse phase 20 R2 (Applied Biosystems, 1-1128-02) was used as chromatographic columns for desalting and upconcentration of the digested protein sample prior to spectrometric analysis. The peptide digest was treated and loaded on MALDI target as described by Sørensen et al. (2009) [34].

\section{Identification of proteins by MALDI-TOF MS}

A MALDI-TOF-TOF instrument (4800 Proteomics analyzer, Applied Biosystems, Foster City, CA) was used to identify proteins. The MS/MS spectra were analysed using Data Explore v4.6 (Applied Biosystems). Mascot MS/MS Ions Search (Matrix Science, http://www. matrixscience.com) was used to search for matching protein sequences within the NCBI database (http:// www.ncbi.nlm.nih.gov/). The taxonomy was restricted to C. jejuni. The mass tolerance was limited to $70 \mathrm{ppm}$ for peptide mass fingerprinting and to $0.6 \mathrm{Da}$ for peptide sequence data.

\section{Primer design and quantitative real time PCR (qRT-PCR) validation of proteome data}

To examine if there is any correlation between induced proteins during acid stress with changes in mRNA level, a qRT-PCR study on C. jejuni strain NCTC 11168 was performed. Besides the induced proteins, the expression of the ferric uptake regulator (fur) was also included since it has been shown that Fur regulates genes involved in iron transport, metabolisms and oxidative stress defence [18-20]. The following were selected as internal and reference genes: $l p x C$ (encoding UDP-3-O[3-hydroxymyristoyl] $\mathrm{N}$-acetylglucosamine deacetylase) [24] and rpoA (encoding the $\alpha$-subunit of the RNA polymerase) (Table 2). The Primer Express software version 2.0 (Applied Biosystems) was used to design primers. PCR primers (Table 2) were purchased from TAG Copenhagen (Copenhagen, Denmark).

After acid stress exposure (same procedure as for the proteomic study), $3 \mathrm{ml}$ culture was mixed with $6 \mathrm{ml}$ RNA-protect (Qiagen) to stabilize RNA and incubated at room temperature for 30 minutes. The mixture was centrifuged. For enzymatic lysis of the cells, the pellet was dissolved in $100 \mu \mathrm{l}$ TE buffer ( $30 \mathrm{mM}$ Tris-Cl, $1 \mathrm{mM}$ EDTA, pH 8.0) containing $15 \mathrm{mg} / \mathrm{ml}$ lysozyme, and added to $10 \mu$ l proteinase K (Qiagen) and incubated for 10 minutes at room temperature. For RNA purification and isolation, the RNeasy Mini Kit (Qiagen, 74104) was used and the included procedure was followed. To eliminate genomic DNA from the isolated RNA, the RNaseFree DNase set was used (Qiagen). First, the samples were measured out to $0.1 \mu \mathrm{g}$ RNA thereafter cDNA was synthesized using the TaqMan Reverse Transcription Reagens (N8080234, Applied system). Each sample was prepared in triplicate resulting in a volume of $20 \mu \mathrm{l}$ containing $5 \mu \mathrm{l}$ cDNA, $10 \mu \mathrm{l} 2 \times$ Power SYBR green PCR mix (Applied Biosystems) and final concentration of 0.9 $\mathrm{pmol} / \mu \mathrm{l}$ of forward and reverse primer.

For amplification of PCR products and quantification of produced cDNA SYBR Green, the 7500 fast real-time PCR system (Applied Biosystems) was used. The thermocycling conditions were $55^{\circ} \mathrm{C}$ for 2 min (uracil-N-glycolyase activation), $95^{\circ} \mathrm{C}$ for $10 \mathrm{~min}$ (Taq activation and uracil-N-glycolyase de-activation) followed by 40 cycles of $95^{\circ} \mathrm{C}$ min for $15 \mathrm{sec}$ and $60^{\circ} \mathrm{C}$ for $1 \mathrm{~min}$.

To determine the changes in the relative gene transcription level presented as fold changes, a mathematical model for relative quantification of in RT-PCR was used [35]. The expression level of the specific target during acid stress was compared with the expression level of non-

Table 2 Primers used in qRT- PCR of Campylobacter jejuni NCTC 11168

\begin{tabular}{|c|c|c|c|}
\hline Gene & product & Forward primer $\left(5^{\prime} \rightarrow 3^{\prime}\right)$ & Reverse primer $\left(5^{\prime} \rightarrow 3^{\prime}\right)$ \\
\hline$d p s$ & Bacterioferritin & TTCATAATCTTGTTTGATCA & AAGAGTITTACAACTTGGCG \\
\hline cj0706 & Unknown & GATGAAGAAATCAAAGATATAG & CAAGAACTTCCATTTCAGAT \\
\hline $\operatorname{sod} B$ & Superoxide dismutase & TATCAAAACTTCAAATGGGG & TाTCTAAAGATCCAAATTCT \\
\hline $\operatorname{trx} B$ & Thioredoxin- disulfide reductase & CAATGTATGCGTITTGGTT & CAAGAACTTCCATTTCAGAT \\
\hline ahpC & Alkyl hydroperoxide reductase & GTACTITATGCAGAAGCAGT & CTACCTAGTGGTAAATCATT \\
\hline $\operatorname{mog} A$ & Molybdenum cofactor biosynthesis protein & ACTTTCTAAGCGCATAAGTTCTCC & TACAAGCGGAGGTACAGGTC \\
\hline p19 & 19 kDa periplasmic protein & GATGATGGTCCTCACTATGG & CATTTGGCGTGCCTGTGTA \\
\hline fur & Ferric uptake regulator & ACTCATTACACACCCGAA & TCACCACAAACACCATAAAG \\
\hline IpxC & UDP-3-O-[3-hydroxymyristoyl] N-acetylglucosamine deacetylase & ATGAGTGCGATTAATGCTTA & GGCTTITTAATTACCATAAT \\
\hline rpoA & DNA-directed RNA polymerase subunit alpha & GCACCATAGGATATGCTCCAACT & CCACGCATGCTATCAAATTCAT \\
\hline
\end{tabular}


stressed cells (control). Three individual biological experiments were performed and data presented as an average.

\section{Statistical analysis}

All data from the growth experiments, comprising three replicates, were log transformed and statistically analyzed by SAS statistical software version 9.1 (SAS Institute, Cary, USA). To test for statistically significant differences in growth with various concentrations of methionine in CDB and BHI, a PROC GLM procedure was used. Volume intensity\% differences between the individual proteins were calculated by variance analysis (ANOVA) in Microsoft Excel (version 2007).

\section{Results}

\section{Growth in modified chemically defined broth}

A modified defined broth that supports the growth of all three $C$. jejuni strains at the same level as in a rich medium (BHI) was developed (Figure 1). Ingredients used in the modified CDB for $C$. jejuni strains are shown in Table 1.

The change of protein synthesis during acid exposure was determined by adding radioactively labelled methionine to the modified $\mathrm{CDB}$ during the stress period. In order to minimize the competition between the methionine and the radioactive methionine in the modified $\mathrm{CDB}$, the minimal concentration of methionine in the modified $\mathrm{CDB}$ was determined for the three strains. Strain 327 had a special requirement for methionine which was illustrated by the fact that in its absence, the bacteria started to die already after $24 \mathrm{~h}$. This strain does not possess all the enzymes involved in synthesis of cellular methionine ([29]). The modified CDB with 0.01 $\mathrm{mM}$ methionine was used in $2 \mathrm{D}$ gel analysis because no significant difference in growth was observed between this concentration and the highest concentration (0.1 $\mathrm{mM})$ investigated $\left(P_{305}=0.07, P_{11168}=0.36, P_{327}=0.52\right)$ (Figure 1). The CDB with methionine supported good growth of all 13 strains tested. For nine of the strains the growth and generation times were comparable with BHI, while four of the strains showed either significantly faster or slower growth (unpublished observations). It has been shown that auxotyping markers, except cystine and cysteine, are stable after three cycles of freezing and thawing [30], and it is therefore possible to minimize the workload by preparing batches of double strength stocks and storing these at $-20^{\circ} \mathrm{C}$.

\section{[ ${ }^{35} \mathrm{~S}$ ]-methionine labelling during acid stress}

C. jejuni strains NCTC 11168, 327, and 305 were grown in $\mathrm{CDB}$ containing $0.01 \mathrm{mM}$ methionine at $37^{\circ} \mathrm{C}$ in a microaerophilic atmosphere. Similar numbers of cells in late exponential phase were desirable for comparability between the strains. To achieve cells in the late exponential phase with approximately $1 \times 10^{8} \mathrm{CFU} / \mathrm{ml}$, strains of NCTC 11168 and 327 were grown for 26 hours, whereas strain 305 only required 22 hours.

The $C$. jejuni cells were exposed to relatively mild acid conditions ( $\mathrm{pH} 5.2$ with $\mathrm{HCl}$ and $\mathrm{pH} 5.7$ with acetic acid) to prevent the cells from dying and closing down all metabolic activity. The gastric $\mathrm{pH}$ during a meal has been measured to be 3.9-5.5 [36] and the experimental $\mathrm{pH}$ is therefore within the upper range. The effects of acid exposure on CFU for all strains are illustrated in Figure 2. Strain 305 was the most acid-tolerant strain while strain 327 was the most acid-sensitive at $37^{\circ} \mathrm{C}$. This correlated well with earlier findings showing that strain 305 was more tolerant than strain 327 towards tartaric acid at $4^{\circ} \mathrm{C}$ [23]. Growth of C. jejuni 305 was only slightly reduced during $\mathrm{HCl}$ and acetic acid stress (Figure 2C), whereas the number of cells for strain 327 decreased (Figure 2B).

\section{Proteomic analysis and identification of proteins}

Methionine labelled protein extracts from non-stressed, $\mathrm{HCl}$ or acetic acid-exposed cells were subjected to 2Dgel-electrophoresis analysis. The majority of proteins were repressed as expected. Relatively few (up to seven) induced proteins were identified with only five being significantly induced. The intensity (\% volume) was calculated for induced proteins under the following conditions: control, $\mathrm{HCl}$, and acetic acid (Table 3). For strain NCTC 11168 , four proteins $[19 \mathrm{kDa}$ periplasmic protein (p19), thioredoxin-disulfide (TrxB), hypothetical protein Cj0706 (Cj0706) and molybdenum cofactor biosynthesis protein (MogA $)]$ were significantly induced $\left(P_{\mathrm{p} 19, \mathrm{HCl}, \mathrm{Ac}}<0.005\right.$, $\left.P_{\text {TrxB, HCl }}=0.009, P_{\mathrm{Cj} 0706, \mathrm{Ac}}=0.016, P_{\mathrm{MogA}, \mathrm{HCl}, \mathrm{Ac}}<0.03\right)$. Volume\% of bacterioferritin (Dps) during $\mathrm{HCl}$ stress was higher compared with the control, but probably due to the variation of the control this difference was not significant $\left(P_{11168, \text { Dps, } \mathrm{HCl}}=0.061\right)$. For the acid-robust strain 305, Dps, p19, MogA and $\operatorname{TrxB}$ were significantly induced $\left(P_{\mathrm{Dps}, \mathrm{HCl}}=0.0028, P_{\mathrm{p} 19, \mathrm{HCl}}=0.0008, P_{\mathrm{MogA}, \mathrm{HCl}}=0.018\right.$, $\left.P_{\text {TrxB, } \mathrm{HCl}}=0.017\right)$. Fewer proteins were induced in the acid-sensitive strain 327, which was also reduced during the acid stress (Figure 2B). Only induction of $\mathrm{Cj} 0706$ and MogA was observed during $\mathrm{HCl}$ acid stress $\left(P_{\mathrm{Cj0706}, \mathrm{HCl}}=\right.$ $\left.0.0037, P_{\text {MogA, } \mathrm{HCl}}=0.04\right)$. In the case of NCTC 11168 and 305 , the two proteins alkyl hydroperoxide reductase $(\mathrm{AhpC})$ and superoxide dismutase (SodB) had higher\% volume intensity than for the control indicating induction; however the differences were not significant. A reference profile of proteins separated by $2 \mathrm{D}$-electrophoresis for $C$. jejuni 305 exposed to $\mathrm{HCl}$ stress $(\mathrm{pH} 5.2)$ is shown in Figure 3.

\section{Quantitative RT-PCR}

Transcriptomic analysis using qRT-PCR technique was performed to determine if the proteins induced during 
Table 3 Induced proteins (\% volume intensity) during $\mathrm{HCl}$ (pH 5.2) and acetic acid (pH 5.7) exposure in C. jejuni NCTC $11168, C$. jejuni 305 and $C$. jejuni 327 at $37^{\circ} \mathrm{C}$ in chemically defined broth

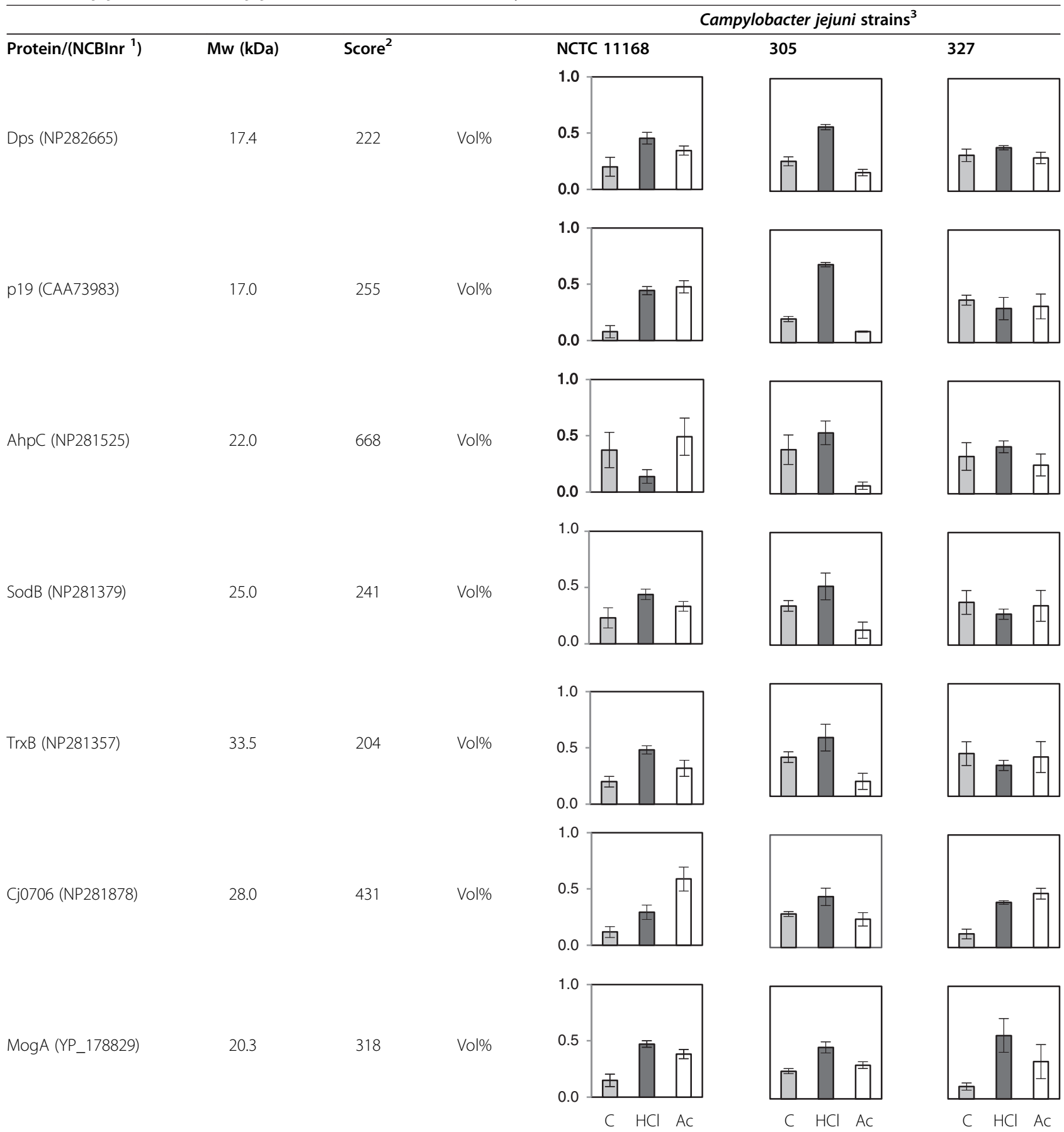

Dps: Bacterioferritin, p19: 19 kDa periplasmic protein, AhpC: Alkyl hydroperoxide reductase, SodB: Superoxide dismutase (Fe), TrxB: Thioredoxin-disulfide reductase, Cj0706: hypothetical protein, MogA: Molybdenum cofactor biosynthesis protein.

Columns: light grey: control (C), dark grey: $\mathrm{HCl}$ stressed cells $(\mathrm{HCl})$, white: Acetic acid stressed cells (Ac).

${ }^{1}$ Identification was based on Mascot MS/MS lon Search using sequence data from the database NCBInr.

${ }^{2}$ Mowse Score (Score).

${ }^{3}$ The intensity of the induced proteins was estimated by Image MasterTM 2D Platinum and \% volume intensity was calculated.

The intensity of the protein spots was analyzed using the Image MasterTM 2D Platinum (version 5.0, Amersham Biosciences, Melanie). Three biological independent replicates was performed and \% volume intensity was calculated as: \% volume intensity control (protein $\mathrm{x})^{=}$volume intensity /(volume intensity control + volume intensity $\mathrm{HCl}+$ volume intensity acetic acid). 
acid stress were induced at transcription level. Figure 4 illustrates the transcription profiles represented by fold

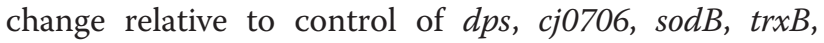
$a h p C, \operatorname{mog} A, p 19$ and fur during $\mathrm{HCl}$ and acetic acid stress for strain NCTC 11168. Interestingly, the transcriptomic data did not correspond completely with the proteomic data (Figure 4). The increased gene expression of $\operatorname{trx} B\left(P_{\mathrm{HCl}}=0.009\right)$ and $p 19\left(P_{\mathrm{HCl}, \mathrm{Ac}}<0.05\right)$ during acid stress corresponded well with enhanced protein production. Especially noteworthy is the high acid stress response of $p 19$ gene compared with the other genes. Proteins such as SodB and AhpC, which were not significantly induced in NCTC 11168, were, however, over-expressed at transcription level during acetic acid exposure $\left(P_{s o d B}\right.$, Ac $\left.=0.03, P_{a h p C, \text { Ac }}=0.000\right)$. The regulator Fur was included in the qRT-PCR study because a search of putative Fur-regulated genes indicated that genes involved in iron-transport genes such as $p 19$, cj0178, ceuB, cfrA, chuA, exbB, feoB and cfhuA and the iron-storage genes such as $d p s$, ferritin (cft) and cj0241 all contained Fur box promoters [37]. Fur was not induced in the proteomic study, but there was a tendency, however not significant, that fur was overexpressed during acetic acid stress $\left(P_{f u r, \text { Ac }}=0.06\right)$.

\section{Discussion}

Proteome analysis for Campylobacter during acid stress revealed different protein profiles between the strains and the type of acid used. The production of induced proteins during acid stress was measured using radioactive

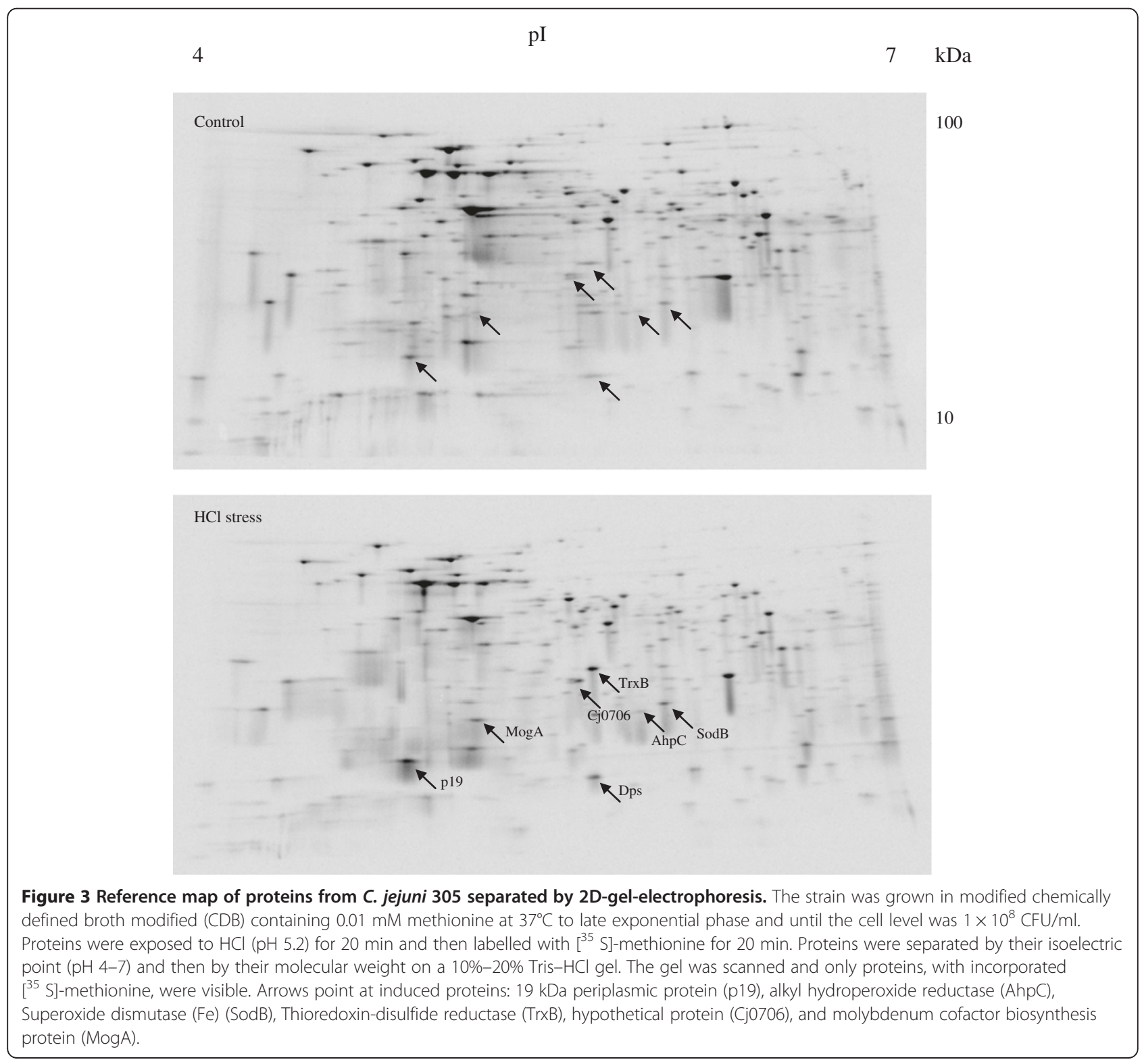


methionine labelling and 2D-gel-electrophoresis in a defined medium after the cultures had been exposed to a strong ( $\mathrm{HCl}, \mathrm{pH} 5.2)$ and a weak (acetic acid, $\mathrm{pH}$ 5.7) acid. Relatively few proteins (up to seven) were induced. However, only two were observed in the most acid-sensitive strain (327). The low number of induced proteins in this strain may be due to a shutdown of the metabolic activity as a result of cell death. In the sequenced strain NCTC 11168 , both $\mathrm{HCl}$ and acetic acid exposure caused induction of proteins while in the most robust strain (305), marked protein induction was primarily seen with $\mathrm{HCl}$. These differences reflect the strain variations in acid sensitivity and probably also the different mode of action of the strong and weak acid on the bacteria cell.

In a comparable proteomic study of the more acidtolerant bacteria E. coli and Salmonella, a 1.5-4 fold induction of 13 proteins (E. coli) and a 2-14 fold induction of 19 proteins (Salmonella) were found when cells were shifted from $\mathrm{pH} 7$ to 5 (phosphoric acid) [38]. The higher number of induced proteins in E. coli and Salmonella compared with what we observed may be due to the fact that $C$. jejuni lack the common acid resistance systems [10-12] and the global stress regulator protein RpoS, as well as the fact that the $C$. jejuni genome is small $(1,660 \mathrm{kbp})$ [13]. Of course, small experimental differences and types of acid stress may influence the outcome as well.
The effect of the low $\mathrm{pH}$ on the bacterial cell is complex because it is interconnected with other factors such as oxygen stress, growth phase and produced metabolites [39]. Most of the proteins observed during acid stress in this study, such as SodB, AhpC, and Dps, have been associated with oxidative stress [40-43]. However, these proteins have also shown to be acid induced in $E$. coli $[39,44,45]$, suggesting multiple protective mechanisms. This link has further been supported by a recent Campylobacter transcriptomic study where upregulation of numerous genes including $\operatorname{ahp} C, \operatorname{sod} B$ and p19 during $\mathrm{HCl}$ exposure were reported [24]. The central role for Dps in acid tolerance response in C. jejuni is supported in a study with a $d p s$ E. coli mutant [45] and in an acid challenge study with Salmonella [26]. In E. coli, Dps has multi functional properties such as DNA binding, iron sequestration, ferrioxidase activity, and a central role for several stress responses - including acid stress [26]. Oxidative stress and free iron are closely connected [46], and it has been shown that decreasing $\mathrm{pH}$ results in enhanced iron-mediated lipid peroxidation processes [47]. Via the Fenton reaction, free iron can react with $\mathrm{H}_{2} \mathrm{O}_{2}$ and generate cell-damaging hydroxyl radicals $(\cdot \mathrm{OH})[48,49]$. Regulation of free $\mathrm{Fe}^{2+}$ is therefore essential for cellular activities. Iron storage proteins indirectly contribute to oxidative stress defence by storing iron in an inactive form thereby preventing

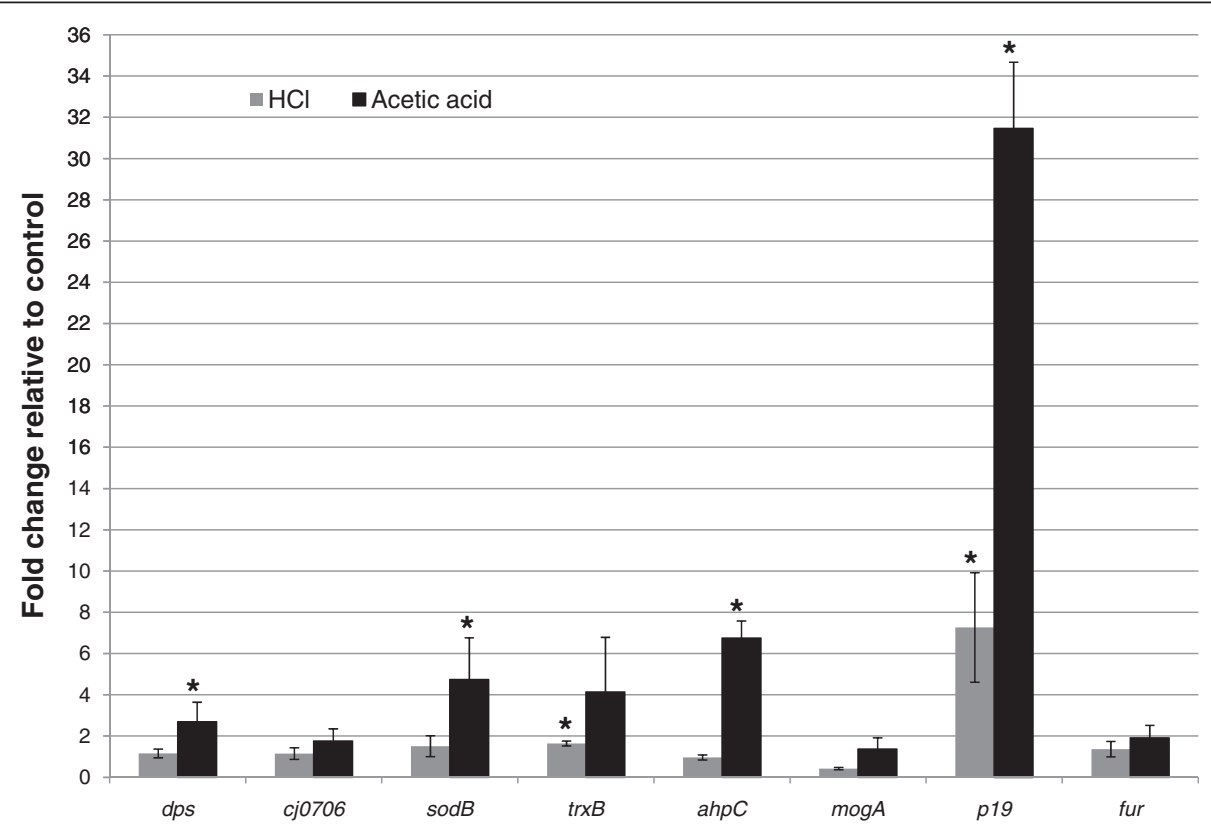

Figure 4 Relative change in transcription level during acid stress of selected genes: $d p s, c j 0706, \operatorname{sod} B, \operatorname{trx} B, \operatorname{ahp} C, \operatorname{mog} A, p 19$ and $\operatorname{fur}$ analyzed by qRT-PCR. C. jejuni strain NCTC 11168 was grown to $1 \times 10^{8} \mathrm{CFU} / \mathrm{ml}$ and exposed to $\mathrm{HCl}(\mathrm{pH}$ 5.2) and acetic acid (pH 5.7). The expression level of acid stressed for a specific gene was compared with unstressed cells and the horizontal line illustrates the fold change at 1.0 for the reference genes $(r p \circ A$ and $I p \times C)$. Fold changes and standard deviations were calculated from the outcome of qRT-PCR runs from three microbiological independent experiments. Genes marked with an asterisk are significantly over-expressed compared with genes from nonstressed cells. 
formation of harmful hydroxyl radicals. At the same time, it is also important to ensure enough iron for metabolic processes. The acid-induced protein Dps has in $C$. jejuni shown to be involved in superoxide and peroxide defence [41] and it is likely that the induction of Dps is a consequence of the iron released upon acid stress.

The induced $19 \mathrm{kDa}$ protein (Cj1659) is a wellconserved periplasmic protein in C. jejuni and Campylobacter coli species [50] which previously was found to be Fur like (ferric uptake regulator) and iron regulated [20]. The p19 system is associated with an ABC iron transport system (cj1659-cj1663) [46] and up-regulation of the $19 \mathrm{kDa}$ protein therefore indicates a way to control the intracellular iron level during acid stress.

The thioredoxin system is composed of both $\operatorname{TrxB}$ and NADPH. In E. coli, TrxB interacts with unfolded and denatured proteins in a way comparable with molecular chaperones which are involved in proper folding of misfolded proteins after stress [51]. A similar function of TrxB in C. jejuni might be possible as a part of the acid defence mechanisms. TrxB might mediate alkyl hydroperoxide reductase $(\mathrm{AhpC})$ as is the case of $\mathrm{H}$. pylori $[37,52]$.

During the acid stress response, the enzyme MogA was induced, which to our knowledge has not been related to acid response before. However, an unpublished microarray study supported our result with acid exposure conditions comparable with our study $(\mathrm{HCl} \mathrm{ex-}$ posure at $\mathrm{pH} 5.0$ in strain NCTC 11168). After 10 minutes up-regulation $\operatorname{mog} A$ was measured, but only on the limit of the statistical threshold (Arnoud van Vliet, personal communications). MogA catalyzes the incorporation of molybdenum (Mo) into molybdopterin to form molybdenum cofactor (MoCo), a cofactor in molybdoenzymes [53]. Some molybdoenzymes in E. coli contain a modified form of MoCo. By transferring a GMP (guanosine monophosphate) to the terminal phosphate of $\mathrm{MoCo}$, a molybdenum guanine dinucleotide (MGD) is formed. MGD is present in the enzymes formate dehydrogenase (FdhA) and nitrate reductase (NapA) in $E$. coli $[54,55]$. The periplasmic two-subunit complex, $C$. jejuni NAP, is considered as an electron acceptor [56] and the enzyme is encoded by napAGHBLD [13]. The NapA is a $\sim 105 \mathrm{kDa}$ catalytic subunit protein that binds the cofactor MGD. Basically, during electron transport at low $\mathrm{O}_{2}$, the molybdenum-containing enzyme nitrate reductase reduces $\mathrm{NO}_{3}^{-}$to $\mathrm{NO}_{2}^{-}$by consuming $2 \mathrm{H}^{+}$. A transcriptional profile of C. jejuni NCTC 11168 after exposure to $\mathrm{HCl}$ stress resulted in a transiently or constantly up-regulated $n a p G H B$ and $f d h A$ [24], indicating that MogA most likely is part of an acid stress response.

The weak induction of SodB and $\mathrm{AhpC}$ indicate that the enzymatic oxidative stress defence play a role during acid stress. AhpC eliminates oxidative damaging compounds by converting alkyl hydroperoxides to the corresponding alcohol [37], and during this reaction a proton is consumed. SodB eliminates the damaging super oxides $\left(\mathrm{O}_{2}^{-}\right)[37,57]$, and in this reaction, protons are also consumed thereby preventing acidification of the cytoplasm. The elimination of $\mathrm{O}_{2}^{-}$and $\mathrm{H}^{+}$by $\mathrm{SodB}$ generates $\mathrm{H}_{2} \mathrm{O}_{2}$, another stress factor. If free $\mathrm{Fe}^{2+}$ is present in the cell, the produced $\mathrm{H}_{2} \mathrm{O}_{2}$ can form hydroxyl radicals $(\cdot \mathrm{OH})$, which may directly damage DNA. This may explain the induced production of Dps that reversibly binds iron. The produced $\mathrm{H}_{2} \mathrm{O}_{2}$ can be removed by catalase (KatA) which converts $\mathrm{H}_{2} \mathrm{O}_{2}$ to $\mathrm{H}_{2} \mathrm{O}$ and $\mathrm{O}_{2}$ [37,57]. In contrast to a transcriptional study where an up-regulation of katA gene was noticed after acid exposure [24], induction of KatA was not observed in this proteomic study. Since $C$. jejuni is sensitive towards oxygen and lacks numerous oxidative stress regulators such as SoxRS and OxyR [13], the cell might be in a constantly oxygen-alert state in order to remove reactive oxygen species and damaging components from acid stress.

No induction of heat shock proteins (Hsps) as chaperones or proteases were observed during acid stress in this study. A transcriptional study found an upregulation of $c l p B, d n a K$, grpE, groEL/ES and htrA [24]. One explanation could be the sensitivity of 2D-gelelectrophoresis for proteomic analysis as mentioned above and the detection limit due to molecular size and isoelectric point (pI) of the proteins. The Hsps, ClpP and GroES have molecular masses close to the maximum and minimum detection size, respectively, and HtrA has a pI of 9.6 which is outside the pI range of the system used here.

Acid exposure of C. jejuni NCTC 11168 was related to changes in gene expression and synthesis of acid stress proteins. However, comparison of the proteomic and transcription study showed a limited correlation between induced proteins and over-expression of genes. A recent proteomic study with acid adaptation of Salmonella enterica also [26] found a limited correlation between the outcomes of the transcriptional (qRT-PCR) versus translational (2D-gel) studies. The lack of corresponding results may be due to the lifetime of the RNA and the time from transcription to translation.

\section{Conclusions}

It can be concluded that the three $C$. jejuni strains, at the phenotypic and proteomic level, responded differently to the acid stresses. We demonstrated that acid stress induces production of several proteins normally involved in iron control and oxidative stress defence in C. jejuni. This work has contributed to the understanding of what occurs in the C. jejuni cells during acid stress. 


\section{Authors' contributions}

TIBIR: performed all experiments, analysed data, wrote the paper and calculated the statistics. MTW: involved in the qRT-PCR. RLA: Helped with the setup of 2D-gel electrophoresis, data analysis of 2D-gel experiments and correction of paper. SKN: supervising, discussion of results and revision of the manuscript. All the authors have given approval of the manuscript.

\section{Acknowledgements}

This work was financially supported by the Danish Food Industry Agency. We acknowledge Bjarne Albrektsen for excellent technical assistance during development and optimization of the chemically defined broth; Andrea Maria Lorentzen from the University of Southern Denmark, who has been a great help in identifying proteins; and Søs Inger Nielsen for excellent technical assistance with qRT-PCR runs. Dr. Thomas Alter, Freie Universitet Berlin, generously provided the strains 305 and 327.

\section{Author details}

'Department of Food Science, Faculty of Sciences Copenhagen University, Rolighedsvej 30, 1958, Frederiksberg C, Denmark. ' Division of Food Microbiology, National Food Institute, Technical University of Denmark, Mørkhøj Bygade 19, 2860, Søborg, Denmark.

Received: 2 March 2012 Accepted: 20 July 2012

Published: 13 August 2012

\section{References}

1. Birk T, Knøchel S: Fate of food-associated bacteria in pork as affected by marinade, temperature, and ultrasound. J Food Prot 2009, 72(3):549-555.

2. Lin J, Lee IS, Frey J, Slonczewski JL, Foster JW: Comparative analysis of extreme acid survival in Salmonella typhimurium, Shigella flexneri, and Escherichia coli. J Bacteriol 1995, 177(14):4097-4104.

3. Murphy C, Carroll C, Jordan KN: Induction of an adaptive tolerance response in the foodborne pathogen, Campylobacter jejuni. FEMS Microbiol Lett 2003, 223(1):89-93.

4. Smibert RM: The genus Campylobacter. Annu Rev Microbiol 1978, 32:673-709.

5. Audia JP, Webb CC, Foster JW: Breaking through the acid barrier: an orchestrated response to proton stress by enteric bacteria. Int J Med Microbiol 2001, 291(2):97-106.

6. Rao KA, Yazaki E, Evans DF, Carbon R: Objective evaluation of small bowel and colonic transit time using $\mathrm{pH}$ telemetry in athletes with gastrointestinal symptoms. Br J Sports Med 2004, 38(4):482-487.

7. Baik HS, Bearson S, Dunbar S, Foster JW: The acid tolerance response of Salmonella typhimurium provides protection against organic acids. Microbiology 1996, 142(Pt 11):3195-3200.

8. Cotter PD, Gahan CG, Hill C: Analysis of the role of the Listeria monocytogenes FOF1 -AtPase operon in the acid tolerance response. Int Food Microbiol 2000, 60(2-3):137-146.

9. Schneider E, Altendorf K: Bacterial adenosine 5'-triphosphate synthase (F1F0): purification and reconstitution of F0 complexes and biochemical and functional characterization of their subunits. Microbiol Rev 1987, 51(4):477-497.

10. Merrell DS, Camilli A: The cadA gene of Vibrio cholerae is induced during infection and plays a role in acid tolerance. Mol Microbiol 1999 34(4):836-849.

11. Park YK, Bearson B, Bang SH, Bang IS, Foster JW: Internal pH crisis, lysine decarboxylase and the acid tolerance response of Salmonella typhimurium. Mol Microbiol 1996, 20(3):605-611.

12. Richard HT, Foster JW: Acid resistance in Escherichia coli. Adv Appl Microbiol 2003, 52:167-186

13. Parkhill J, Wren BW, Mungall K, Ketley JM, Churcher C, Basham D, Chillingworth T, Davies RM, Feltwell T, Holroyd S, Jagels K, Karlyshev AV, Moule S, Pallen MJ, Penn CW, Quail MA, Rajandream MA, Rutherford KM, van Vliet AH, Whitehead S, Barrell BG: The genome sequence of the foodborne pathogen Campylobacter jejuni reveals hypervariable sequences. Nature 2000, 403(6770):665-668.

14. Magnusson LU, Farewell A, Nystrom T: ppGpp a global regulator in Escherichia coli. Trends Microbiol 2005, 13(5):236-242.

15. Foster JW: Escherichia coli acid resistance: tales of an amateur acidophile. Nat Rev Microbio/ 2004, 2(11):898-907.
16. Lee IS, Lin J, Hall HK, Bearson B, Foster JW: The stationary-phase sigma factor sigma $S(R p o S)$ is required for a sustained acid tolerance response in virulent Salmonella typhimurium. Mol Microbiol 1995, 17(1):155-167.

17. Svensson SL, Frirdich E, Gaynor EC: Survival strategies of Campylobacter jejuni: stress responses, the viable but nonculturable state, and biofilms In Campylobacter. 3rd edition. Edited by Nachmkin I, Szymanski CM, Blaser MJ. Washington DC, USA: ASM Press; 2008:571-590

18. Holmes K, Mulholland F, Pearson BM, Pin C, McNicholl-Kennedy J, Ketley JM, Wells JM: Campylobacter jejuni gene expression in response to iron limitation and the role of Fur. Microbiology 2005, 151(Pt 1):243-257.

19. Palyada K, Threadgill D, Stintzi A: Iron acquisition and regulation in Campylobacter jejuni. J Bacteriol 2004, 186(14):4714-4729.

20. van Vliet $A H$, Wooldridge $K G$, Ketley JM: Iron-responsive gene regulation in a Campylobacter jejuni fur mutant. J Bacteriol 1998, 180(20):5291-5298.

21. Bijlsma JJ, Gerrits MM, Imamdi R, Vandenbroucke-Grauls CM, Kusters JG: Urease-positive, acid-sensitive mutants of Helicobacter pylori: ureaseindependent acid resistance involved in growth at low $\mathrm{pH}$. FEMS Microbiol Lett 1998, 167(2):309-313.

22. Hall HK, Foster JW: The role of fur in the acid tolerance response of Salmonella typhimurium is physiologically and genetically separable from its role in iron acquisition. J Bacteriol 1996, 178(19):5683-5691.

23. Birk T, Grønlund AC, Christensen BB, Knøchel S, Lohse K, Rosenquist H: Effect of organic acids and marination ingredients on the survival of Campylobacter jejuni on meat. J Food Prot 2010, 73(2):258-265.

24. Reid AN, Pandey R, Palyada K, Naikare H, Stintzi A: Identification of Campylobacter jejuni genes involved in the response to acidic $\mathrm{pH}$ and stomach transit. Appl Environ Microbiol 2008, 74(5):1583-1597.

25. Birrell GW, Brown JA, Wu HI, Giaever G, Chu AM, Davis RW, Brown JM: Transcriptional response of Saccharomyces cerevisiae to DNA-damaging agents does not identify the genes that protect against these agents. Proc Natl Acad Sci USA 2002, 99(13):8778-8783

26. Calhoun LN, Liyanage R, Lay JO Jr, Kwon YM: Proteomic analysis of Salmonella enterica serovar Enteritidis following propionate adaptation. BMC Microbiol 2010, 10:249.

27. Foster JW: Microbial responses to acid stress. In Bacterial stress response Edited by Storz G, Hengge-Aronis R. Washington DC, USA: ASM Press; 2000:99-115.

28. Takamiya M, Ozen A, Rasmussen M, Alter T, Gilbert T, Ussery DW, Knøchel S: Genome sequences of two stress-tolerant Campylobacter jejuni poultry strains, 305 and DFVF1099. J Bacteriol 2011, 193(19):5546-5547.

29. Takamiya M, Ozen A, Rasmussen M, Alter T, Gilbert T, Ussery DW, Knøchel S: Genome Sequence of Campylobacter jejuni strain 327, a strain isolated from a turkey slaughterhouse. Stand Genomic Sci 2011, 4(2):113-122.

30. Tenover FC, Knapp JS, Patton C, Plorde JJ: Use of auxotyping for epidemiological studies of Campylobacter jejuni and Campylobacter coli infections. Infect Immun 1985, 48(2):384-388

31. Kelly DJ: Metabolism, electron transport and bioenergetis of Campylobacter jejuni: Implications for understanding life in the gut and survival in the environment. In Campylobacter, Molecular and cellular biology. Edited by Ketley J, Konkel ME, Norfilk NR. 180JA, U.K: Horizone Bioscience; 2005:275-292

32. Kegg Pathway Database; 2010. http://www.genome.jp/kegg/pathway.html.

33. Foster JW: The acid tolerance response of Salmonella typhimurium involves transient synthesis of key acid shock proteins. J Bacterio/ 1993, 175(7):1981-1987.

34. Sørensen LM, Lametsch R, Andersen MR, Nielsen PV, Frisvad JC: Proteome analysis of Aspergillus niger: lactate added in starch-containing medium can increase production of the mycotoxin fumonisin B2 by modifying acetyl-CoA metabolism. BMC Microbiol 2009, 9:255.

35. Pfaffl MW: A new mathematical model for relative quantification in realtime RT-PCR. Nucleic Acids Res 2001, 29(9):e45

36. Russell TL, Berardi RR, Barnett UL, Dermentzoglou LC, Jarvenpaa KM, Schmaltz SP, Dressman JB: Upper gastrointestinal pH in seventy-nine healthy, elderly, North American men and women. Pharm Res 1993, 10(2):187-196

37. van Vliet AH, Ketley JM, Park SF, Penn CW: The role of iron in Campylobacter gene regulation, metabolism and oxidative stress defense. FEMS Microbiol Rev 2002, 26(2):173-186.

38. Hickey EW, Hirshfield IN: Low-pH-induced effects on patterns of protein synthesis and on internal pH in Escherichia coli and Salmonella typhimurium. Appl Environ Microbiol 1990, 56(4):1038-1045. 
39. Stancik LM, Stancik DM, Schmidt B, Barnhart DM, Yoncheva YN, Slonczewski $J$ : $\mathrm{pH}$-dependent expression of periplasmic proteins and amino acid catabolism in Escherichia coli. J Bacteriol 2002, 184(15):4246-4258.

40. Baillon ML, van Vliet AH, Ketley JM, Constantinidou C, Penn CW: An ironregulated alkyl hydroperoxide reductase $(\mathrm{AhpC})$ confers aerotolerance and oxidative stress resistance to the microaerophilic pathogen Campylobacter jejuni. J Bacteriol 1999, 181(16):4798-4804

41. Ishikawa T, Mizunoe Y, Kawabata S, Takade A, Harada M, Wai SN, Yoshida S: The iron-binding protein Dps confers hydrogen peroxide stress resistance to Campylobacter jejuni. J Bacteriol 2003, 185(3):1010-1017

42. Pesci EC, Cottle DL, Pickett CL: Genetic, enzymatic, and pathogenic studies of the iron superoxide dismutase of Campylobacter jejuni. Infect Immun 1994, 62(7):2687-2694.

43. Purdy D, Cawthraw S, Dickinson JH, Newell DG, Park SF: Generation of a superoxide dismutase (SOD)-deficient mutant of Campylobacter coli: evidence for the significance of SOD in Campylobacter survival and colonization. Appl Environ Microbiol 1999, 65(6):2540-2546.

44. Blankenhorn D, Phillips J, Slonczewski JL: Acid- and base-induced proteins during aerobic and anaerobic growth of Escherichia coli revealed by two-dimensional gel electrophoresis. J Bacteriol 1999, 181(7):2209-2216.

45. Choi SH, Baumler DJ, Kaspar CW: Contribution of dps to acid stress tolerance and oxidative stress tolerance in Escherichia coli 0157:H7. Appl Environ Microbiol 2000, 66(9):3911-3916.

46. Stintzi AA, van Vliet AHM, Ketley JM: Iron metabolism, transport, and regulation. In Campylobacter. 3rd edition. Edited by Nachmkin I, Szymanski CM, Blaser MJ. Washington, DC, USA: ASM Press; 2008:591-610.

47. Schafer FQ, Buettner GR: Acidic pH amplifies iron-mediated lipid peroxidation in cells. Free Radic Biol Med 2000, 28(8):1175-1181.

48. Halliwell B, Gutteridge JM: Free radicals, lipid peroxidation, and cell damage. Lancet 1984, 2(8411):1095.

49. Pierre $J$, Fontecave M: Iron and activated oxygen species in biology: the basic chemistry. Biometals 1999, 12(3):195-199.

50. Janvier B, Constantinidou C, Aucher P, Marshall ZV, Penn CW, Fauchere L: Characterization and gene sequencing of a 19-kDa periplasmic protein of Campylobacter jejuni/coli. Res Microbiol 1998, 149(2):95-107.

51. Kern R, Malki A, Holmgren A, Richarme G: Chaperone properties of Escherichia coli thioredoxin and thioredoxin reductase. Biochem J 2003, 371(Pt 3):965-972.

52. Baker LM, Raudonikiene A, Hoffman PS, Poole LB: Essential thioredoxindependent peroxiredoxin system from Helicobacter pylori: genetic and kinetic characterization. J Bacteriol 2001, 183(6):1961-1973.

53. Liu MT, Wuebbens MM, Rajagopalan KV, Schindelin H: Crystal structure of the gephyrin-related molybdenum cofactor biosynthesis protein MogA from Escherichia coli. J Biol Chem 2000, 275(3):1814-1822.

54. Rajagopalan KV, Johnson JL: The pterin molybdenum cofactors. J Biol Chem 1992, 267(15):10199-10202.

55. Sanishvili R, Beasley S, Skarina T, Glesne D, Joachimiak A, Edwards A, Savchenko A: The crystal structure of Escherichia coli MoaB suggests a probable role in molybdenum cofactor synthesis. J Biol Chem 2004, 279(40):42139-42146.

56. Pittman MS, Kelly DJ: Electron transport through nitrate and nitrite reductases in Campylobacter jejuni. Biochem Soc Trans 2005, 33(Pt 1):190-192.

57. Touati D: Iron and oxidative stress in bacteria. Arch Biochem Biophys 2000, 373(1):1-6.

doi:10.1186/1471-2180-12-174

Cite this article as: Birk et al:: Acid stress response and protein induction in Campylobacter jejuni isolates with different acid tolerance. BMC Microbiology 2012 12:174.

\section{Submit your next manuscript to BioMed Central and take full advantage of:}

- Convenient online submission

- Thorough peer review

- No space constraints or color figure charges

- Immediate publication on acceptance

- Inclusion in PubMed, CAS, Scopus and Google Scholar

- Research which is freely available for redistribution

Submit your manuscript at www.biomedcentral.com/submit
C Biomed Central 